Duque-Gamboa, D.N., Arenas Clavijo, A., Posso-Terranova, A., Toro-Perea, N. (2021). Mutualistic interaction of aphids and ants in pepper, Capsicum annuum and Capsicum frutenscens (Solanaceae). Revista de Biología Tropical, 69(2), 626-639. https://doi.org/10.15517/rbt.v69i2.43429

https://doi.org/10.15517/rbt.v69i2.43429

\title{
Mutualistic interaction of aphids and ants in pepper, Capsicum annuum and Capsicum frutenscens (Solanaceae)
}

\author{
Diana Nataly Duque-Gamboa ${ }^{1 *}$; (D) https://orcid.org/0000-0003-1859-8381 \\ Anderson Arenas Clavijo2; (iD https://orcid.org/0000-0001-5639-5273 \\ Andres Posso-Terranova ${ }^{3}$; (D) https://orcid.org/0000-0002-2647-3397 \\ Nelson Toro-Perea ${ }^{4}$; (D https://orcid.org/0000-0002-2835-7285
}

1. Centro de Investigación e Innovación en Bioinformática y Fotónica (CIBioFi), Universidad del Valle, Cali, Colombia; diana.nataly.duque@correounivalle.edu.co (*Correspondence)

2. Departamento de Biología, Universidad del Valle, Cali, Colombia; anderson.arenas@correounivalle.edu.co

3. Seed and Developmental Biology, Global Institute for Food Security - GIFS, University of Saskatchewan, Saskatoon, Canada; andres.posso@usask.ca

4. Centro de Investigación e Innovación en Bioinformática y Fotónica (CIBioFi), Universidad del Valle, Cali, Colombia; nelson.toro@correounivalle.edu.co

Received 10-VIII-2020. Corrected 08-IV-2021. Accepted 06-V-2021.

\begin{abstract}
Introduction: Adequate biological identification is fundamental for establishing integrated pest management programs and identifying the trophic and mutualist relationships that can affect pest population dynamics. Aphids are the main pest of pepper Capsicum spp. (Solanaceae) crops in Southwestern Colombia, due to their role as vectors of viruses. However, the identification of aphid species is complex, limiting the investigations performed to address their interactions with other organisms. Ants and aphids present a facultative mutualistic relationship, that promotes the growth of hemipteran colonies, for this reason, the study of the ecological mutualistic association between aphids and ants is important. Objective: The main objective was to discriminate the aphid species present in commercial crops of Capsicum spp., and to identify the ant community that attends the aphid colonies and its effects on the size of the aphid colonies. Methods: Aphid species, and their ant mutualist, were collected from Capsicum annuum and Capsicum frutescens, in the Cauca valley, Southwestern Colombia. We used the DNA barcoding approach to identify aphid species, and the ants were identified by morphologybased taxonomy. To evaluate the effect of ant care on the size and structure of aphid colonies, generalized linear models were calculated using as the response variables the total number of aphids for each colony and the proportion of nymphs. Results: The aphid species that attack pepper crops, are: Aphis gossypii and Myzus persicae (Hemiptera: Aphididae), with A. gossypii being the species that interacts with ants (19 ant species). A. gossypii colonies attended by ants had larger sizes and more nymphs per colony, than those not attended. Conclusions: Although the aphid-ant interaction is not species-specific, it is necessary to consider its role in the propagation of viral diseases in peppers and to determine how this interaction may affect regional biological control strategies.
\end{abstract}

Key words: Aphis gossypii; Myzus persicae; COI; DNA barcoding; ants.

Herbivorous insects become pests of cultivated systems (Mazzi \& Dorn, 2012), because of the increasing nutritional value of plants via the addition of nitrogen and homogenization of plant communities in the agricultural system (Matson, Parton, Power, \& Swift, 1996; Altieri, 1999; Rusch, Bommarco, \& Ekbom, 2017). Aphids (Hemiptera: Aphididae) are among the 
leading insect pests worldwide due to the physiological stress their feeding generates in their host plants and their ability to transmit phytopathogenic viruses (Goggin, 2007; Brault, Uzest, Monsion, Jacquot, \& Blanc, 2010).

The identification of aphid species is complex due to their evolutionary tendency of losing taxonomically useful morphological characters and their environmental plasticity (Foottit, 1997; Foottit, Maw, Von Dohlen, \& Hebert, 2008). Classical morphological and taxonomical identification involves micrometric measurements of certain characteristics at specific developmental stages, which are usually during the adult stage of the female (Holman, 1974), thus requiring the rearing of insects (Blackman \& Eastop, 2007). The presence of different morphological variants in the same species increases the difficulty of identifying these insects and subsequently identifying and characterizing species-specific relationships at different levels, such as herbivore-host, parasitoid-host and virus-vector relationships (Foottit et al., 2008; Miller \& Foottit, 2009; Nie, Pelletier, Mason, Dilworth, \& Giguère, 2011; Pelletier et al., 2012).

A useful complement in the identification of species of the family Aphididae has been the use of the mitochondrial region called the "DNA barcode", which corresponds to a fragment of approximately 700 base pairs at the 5 'end of the cytochrome c oxidase I (COI) gene (Foottit et al., 2008; Miller \& Foottit, 2009; Chen, Jiang, \& Qiao, 2012). This technique proposed by Hebert, Cywinska and Ball (2003), has allowed for the rapid identification of aphid species by considering genetic distance thresholds specific to this group and comparing the sequences with those available in public reference databases (Coeur d'acier et al., 2014). DNA barcoding has also contributed to the discrimination of cryptic aphid species (Piffaretti et al., 2012), the association of morphological variants with different developmental stages in the same species (Miller \& Foottit, 2009) and the establishment of different morphotypes that a species can present in different host plants (Lokeshwari, Kumar, \& Manjunatha, 2014).

Another advantage of molecular techniques is the identification of species at any developmental stage of the pest (Armstrong \& Ball, 2005). This type of reliable and early detection is of great phytosanitary value because it allows for a timely and adequate response to a potential impact (Armstrong \& Ball, 2005; Mazzi \& Dorn, 2012). At the same time, proper identification of the species is also essential for establishing integrated pest management (IPM) and clarifying different ecological and trophic interactions that may affect the biological control of pests (Foottit, Maw, Havill, Ahern, \& Montgomery, 2009; Pelletier et al., 2012).

Among the different ecological interactions that aphids establish with other organisms, the mutualistic relationship with ants (Hymenoptera: Formicidae) is noteworthy. Although this interaction is facultative and not species-specific (Buckley, 1987; Collins \& Leather, 2002), it contributes to the population growth of aphids, which provide sugar secretions to ants while the ants offer protection from generalist and specialist aphidophagous predators (Styrsky \& Eubanks, 2007; Powell \& Silverman, 2010a). Negative aspects of this interaction may include reduced size and reproductive fitness of aphids and its predation by ants (Billick, Hammer, Reithel, \& Abbot, 2007; Yao, 2014; Hosseini, Hosseini, Katayama, \& Mehrparvar, 2017). This mutualist association can interfere with integrated pest management and this interference is why its description in agricultural systems is relevant.

Aphids are the main pest of the pepper Capsicum spp. in Colombia because they can transmit phytopathogenic viruses of the genera Potyvirus and Cucumovirus (Van Emden \& Harrington, 2003), which affect these crops (Pardey \& García, 2011), and depending on the level of incidence of the disease, and the age of the crop plants at the time of the infection, losses in the crop may reach $100 \%$ (Kenyon, Kumar, Tsai, \& Hughes, 2014). However, the morphological identification of these aphids is complex, aphid species identity and diversity 
are unknown, therefore, the ecological interactions with other insects in this agricultural system are not well identified. For this reason, this study sought to identify both the aphid species present in the pepper crops, cayenne pepper Capsicum annuum L. and tabasco pepper Capsicum frutescens L. (Solanaceae), in Southwestern Colombia, as well as mutualistic ant species associated with the care of aphid colonies and to evaluate the effect of ant care on the size of the aphid colonies. Finally, the present study aimed to explore and illustrate the plant-aphid-ant interaction networks in Capsicum spp. commercial farming systems.

\section{MATERIALS AND METHODS}

Obtaining insects: Commercial crops of Capsicum spp. were visited in seven locations in Valle del Cauca, Southwestern Colombia, Bolivar $\left(04^{\circ} 17^{\prime} 60.0^{\prime \prime} \mathrm{N} \& 76^{\circ} 12^{\prime} 28.8^{\prime \prime}\right.$ W), Roldanillo (4⒉ $4^{\prime} 14.4^{\prime \prime} \mathrm{N} \& 7^{\circ} 08^{\prime} 42.0^{\prime \prime}$ $\left.\mathrm{W} ; 04^{\circ} 28^{\prime} 30.0^{\prime \prime} \mathrm{N} \& 76^{\circ} 07^{\prime} 04.8^{\prime \prime} \mathrm{W}\right)$, Toro

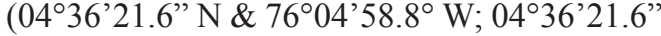
$\left.\mathrm{N} \& 76^{\circ} 05^{\prime} 24.0^{\prime \prime} \mathrm{W}\right)$, Dagua $\left(03^{\circ} 45^{\prime} 10.8^{\circ} \mathrm{N}\right.$ \& 76 39'21.6" W), Guacari (03 $43^{\circ}$ '00.0” N \& 76 $\left.16^{\circ} 30.0^{\prime \prime} \mathrm{W}\right)$, Rozo $\left(03^{\circ} 37^{\prime} 15.2^{\prime \prime} \mathrm{N} \&\right.$ $76^{\circ} 25^{\prime} 14.5^{\prime \prime} \mathrm{W}$; 033' $10.6^{\prime \prime} \mathrm{N} \& 6^{\circ} 23^{\prime} 22.9^{\prime \prime}$ $\mathrm{W})$, Vijes $\left(03^{\circ} 42^{\prime} 18.0^{\prime \prime} \mathrm{N} \& 7^{\circ} 25^{\prime} 48.0^{\prime \prime} \mathrm{W}\right)$; and they included four cayenne pepper $(C$. annuum) and six tabasco pepper (C. frutescens) sampling sites (Fig. 1). Each location was visited at two phenological stages between January (before flowering) and August (flowering and fruiting stage) of 2017. The area analysed corresponds to the inter-Andean valley of the Cauca river, located between the Western and central mountain ranges. In this regional scale, the surface covered is an inter-Andean tectonic depression between $900 \mathrm{~m}$ to $1000 \mathrm{~m}$ of elevation, it presents $23.3 \pm 6^{\circ} \mathrm{C}$ and $79 \pm 24 \% \mathrm{RH}$ (Instituto Geográfico Agustín Codazzi, 1998; Cueto, 2006; Montoya-Colonia, 2010).

Because aphids enter the fields of tabasco pepper crops in Southwestern Colombia from the edges and present an aggregate distribution

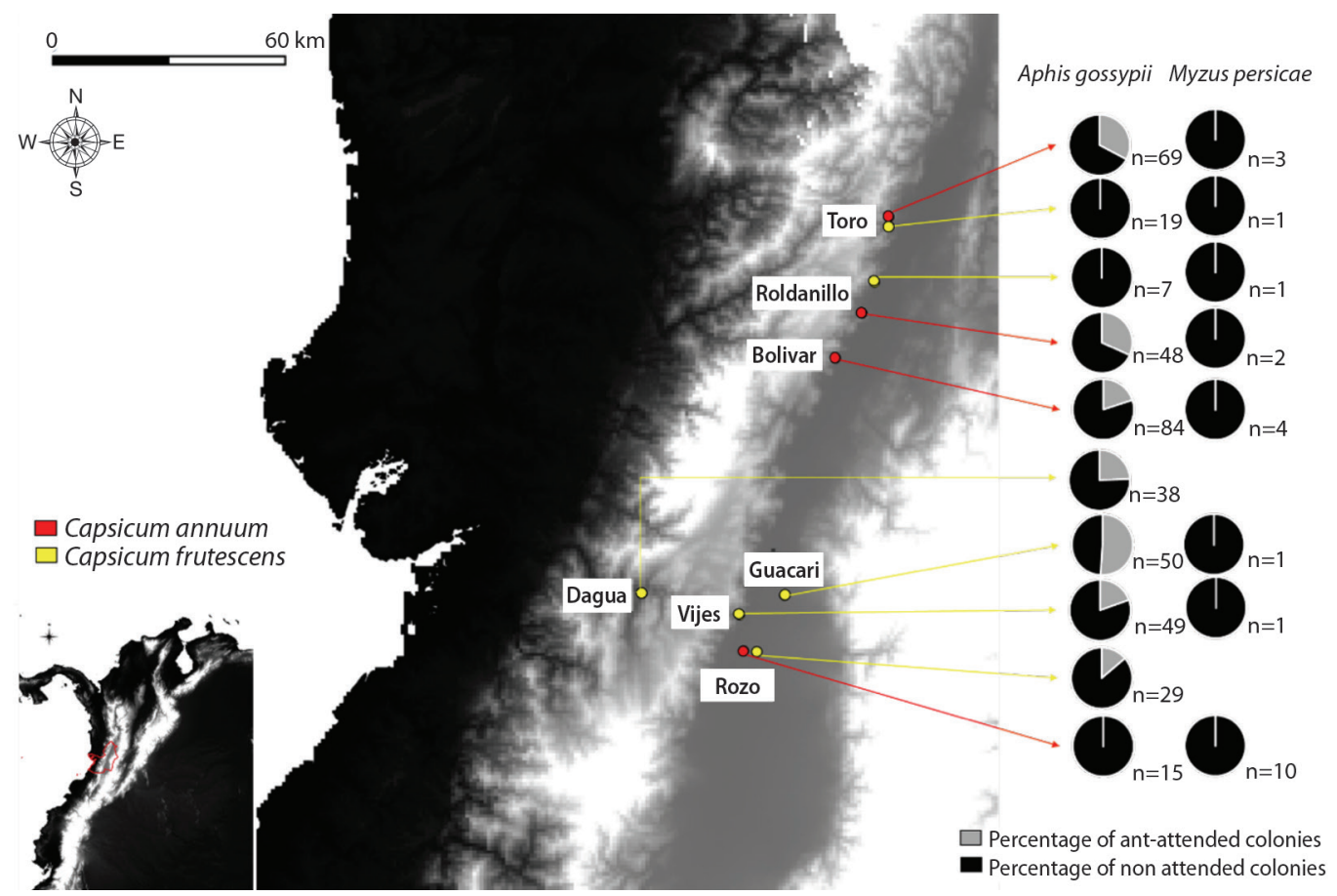

Fig. 1. Geographical location of the sampled sites. Yellow indicates the localities with tabasco pepper $(C$. frutescens $)$ crops and red indicates the localities with cayenne pepper (C. апnиит) crops. 
pattern (Tálaga et al., 2017), a manual sampling of aphids was performed, covering the perimeter of the cultivated area, in plants separated by $20 \mathrm{~m}$ to avoid the collection of aphids belonging to the same colony and to obtain a good representation of the diversity of these insects. The individual colonies of aphids as well as the associated ants that were observed attending the aphid colonies were manually collected in $90 \%$ ethanol, separated in the laboratory, and stored at $-20{ }^{\circ} \mathrm{C}$ until analysis.

Identification of aphids and mutualistic ants: To identify the aphids present in the crops, the apterous adult insects collected were grouped according to the macroscopic morphological characteristics described by Holman (1974). For the DNA extraction and COI sequencing procedures, specimens of each morphological variant were randomly selected in each crop and sampled locality.

DNA extraction was performed using the complete body of each aphid and the commercial animal tissue kit from QIAGEN following the manufacturer's recommendations. Amplification of the COI fragment (658 base pairs) was performed using primers LCO1490 (5' ggtcaacaaatcataaagatattgg-3') and $\mathrm{HCO} 2198$ (5'-taaacttcagggtgaccaaaaaatca-3') (Folmer, Black, Hoeh, Lutz, \& Vrijenhoek, 1994) in 25 $\mu \mathrm{L}$ of amplification cocktail with $1 \mathrm{X}$ PCR buffer solution, $2 \mathrm{mM} \mathrm{MgCl} 2,0.05 \mathrm{mM}$ dNTPs, $0.25 \mu \mathrm{M}$ of each primer, $1 \mathrm{U}$ of Taq DNA polymerase, and 5-10 ng of DNA. The temperature profile for the reaction included an initial denaturation step for $5 \mathrm{~min}$ at $92{ }^{\circ} \mathrm{C}$, which was followed by 35 cycles of $30 \mathrm{~s}$ at 94 ${ }^{\circ} \mathrm{C}, 1 \mathrm{~min}$ at $52{ }^{\circ} \mathrm{C}$, and $1 \mathrm{~min}$ at $72{ }^{\circ} \mathrm{C}$; and a final extension for $5 \mathrm{~min}$ at $72{ }^{\circ} \mathrm{C}$. Sequencing was performed via the specialized supplier Macrogen USA, and the sequences obtained were edited and aligned using Mega 7 (Kumar, Stecher, Tamura, \& Dudley, 2016).

The COI identification sequence was mainly based on three aspects: the neighbour joining (NJ) analysis based on the Kimura twoparameter (K2P) nucleotide substitution model (Kumar et al., 2016), the estimation of genetic distances between COI haplotypes estimated with the K2P model using Mega 7 (Kumar et al., 2016) and a comparison of the similarity and sequence homology of the unique haplotypes obtained for aphids with those available in public databases, such as the NCBI GenBank (Hebert et al., 2003; Ratnasingham \& Hebert, 2007). Sequences representing each haplotype per species on the different host plants were deposited in GenBank under the unique accession codes MK766466-MK766469.

To estimate the genetic distancing thresholds expected for the species found, the haplotypes reported in the NCBI database and their intraspecific and interspecific differentiation values were compared with those obtained by analysing the distance values in the collected aphids via the Automatic Barcode Gap Discovery ABGD programme (Puillandre, Lambert, Brouillet, \& Achaz, 2012).

The identification of ants was performed at the Laboratory of Ant Biology and Ecology, Universidad del Valle (Cali, Colombia) using specialized taxonomic keys (Fernández, Guerrero, \& Delsinne, 2019), the AntWeb v8.41 digital tool (California Academy of Sciences, 2020), and by direct comparison with specimens deposited at the Entomological Museum of Universidad del Valle (MUSENUV).

\section{Mutual association between aphids and} ants: To visualize the structural patterns of the host plant-aphid-ant trophic network, the programme Food Web Designer 3.0 was used (Sint \& Traugott, 2016). To evaluate the effect of ant care on the size and structure of aphid colonies, generalized linear models were calculated using the programme R V3.4.4 (R Core Team, 2018). The response variables were the total number of aphids for each colony and the proportion of nymphs, with the latter used as a measure of the reproductive success of the colony.

\section{RESULTS}

Identification of pest aphids: The 1504 apterous adult insects collected were grouped 
according to the macroscopic morphological characteristics described by Holman (1974) in two groups corresponding to the genera Aphis $(\mathrm{N}=1460)$ and Myzus $(\mathrm{N}=45)$. Aphis presented 4 colour variants, while Myzus presented only one.

Among the 144 specimens selected for the COI characterization, a total of 124 aphids of the genus Aphis were obtained, and they included four colour variants, yellow (21 specimens from tabasco pepper and 18 from cayenne pepper), beige (13 sampled in tabasco pepper and 15 from cayenne pepper), green (22 specimens from tabasco pepper and 19 from cayenne pepper), brown (5 specimens collected in tabasco pepper and 11 from cayenne pepper), while a total of 20 aphids of the genus Myzus were obtained, and they included a single colour pattern in both hosts. The NJ analysis based on the K2P nucleotide substitution model (Fig. 2) indicated that the different morphological groups corresponded to two genetic groups, with each genetic group only presenting one haplotype. The genetic distance estimated with the K2P model among the COI haplotypes was $9.3 \%$. A comparison of the haplotypes obtained with those available in the NCBI database indicated a similarity and homology of sequences of $100 \%$, with the collected specimens in group 1 corresponding to the species Aphis gossypii (Glover, 1877) and those in group 2 corresponding to the species Myzus persicae (Zulser, 1776).

The haplotype sequences of $A$. gossypii (69 haplotypes, 276 sequences) and M. persicae (24 haplotypes, 101 sequences) available in the NCBI were analysed with ABGD software, and variation of less than $2 \%$ was expected at the intraspecific level and the differentiation between these two species ranged between 9 and $11 \%$. These findings indicate that the distance value observed for this marker $(9.3 \%)$ between the two genetic groups of aphids collected in the cultivation of Capsicum spp. (Fig. 2) corresponded to interspecific differentiation.

Mutualistic association between aphids and ants: We found 23 colonies of $M$. persicae, with 19 in cayenne pepper crops and 4 in tabasco pepper; however, none of the colonies showed an association with ants (Fig. 1). We also found a total of 408 colonies of $\mathrm{A}$. gossypii, with 192 in $C$. frutescens and 216 in $C$. annuum; and of these colonies, 46 C. frutescens colonies and 48 C. annuum colonies were attended by ants, for an incidence of ant care of 23.9 and $22.2 \%$, respectively (Fig. 1, Table 1). A total of 19 ant species were recorded from colonies of $A$. gossypii, and they represented four subfamilies and eight tribes, which are

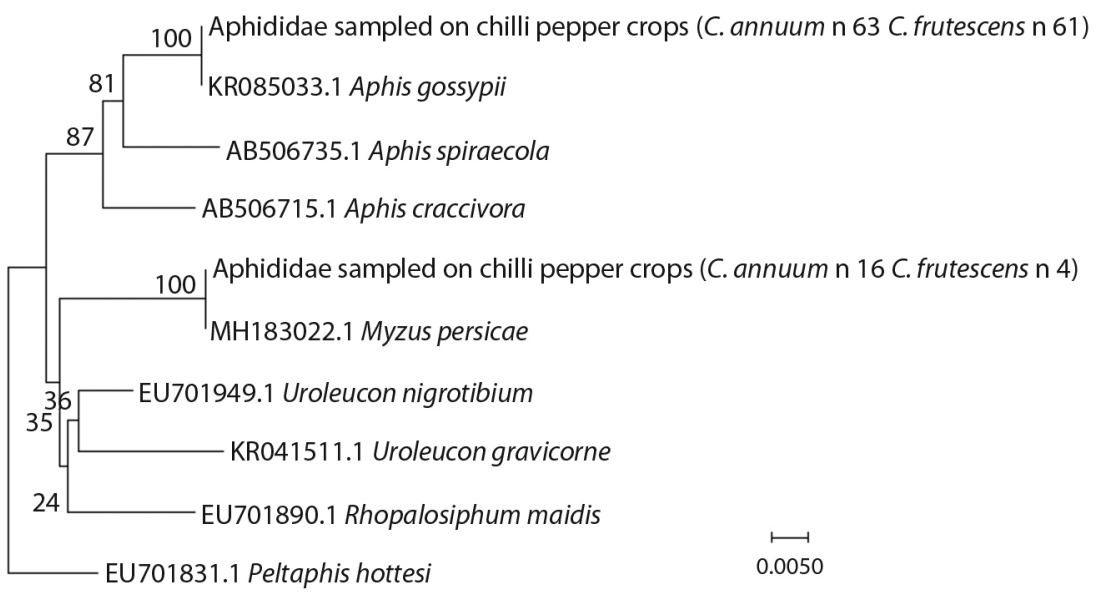

Fig. 2. Neighbour joining (NJ) analysis based on the K2P model with 1000 bootstrap samples using 144 COI sequences of aphids collected in cayenne (C. апnиum) and tabasco (C. frutescens) pepper crops in Southwestern Colombia. 
TABLE 1

Record of ant species that attend colonies of A. gossypii in crops of Capsicum spp. in Southwestern Colombia

\begin{tabular}{|c|c|c|c|c|c|c|c|}
\hline \multirow{2}{*}{ Ant species } & \multicolumn{3}{|c|}{ Cayenne pepper $C$. апnиит } & \multicolumn{4}{|c|}{ Tabasco pepper C. frutescens } \\
\hline & Bolívar & Roldanillo & Toro & Dagua & Guacarí & Rozo & Vijes \\
\hline Azteca instabilis (Smith, 1862) & 0 & 0 & 1 & 0 & 0 & 0 & 0 \\
\hline Brachymyrmex heeri (Forel, 1874) & 2 & 7 & 5 & 0 & 0 & 0 & 6 \\
\hline Brachymyrmex longicornis (Forel, 1907) & 0 & 2 & 2 & 0 & 0 & 0 & 0 \\
\hline Brachymyrmex obscurior (Forel, 1893) & 0 & 0 & 1 & 0 & 0 & 0 & 0 \\
\hline Camponotus brevis (Forel, 1899) & 0 & 0 & 3 & 0 & 0 & 0 & 0 \\
\hline Camponotus lindigi (Mayr, 1870) & 0 & 0 & 0 & 4 & 4 & 0 & 0 \\
\hline Cardiocondyla obscurior (Wheeler, 1929) & 0 & 0 & 0 & 0 & 0 & 0 & 1 \\
\hline Crematogaster abstinens (Forel, 1899) & 0 & 0 & 0 & 0 & 1 & 0 & 0 \\
\hline Dorymyrmex brunneus (Forel, 1908) & 0 & 0 & 1 & 1 & 2 & 1 & 1 \\
\hline Linepithema neotropicum (Wild, 2007) & 0 & 0 & 0 & 0 & 1 & 0 & 0 \\
\hline Monomorium floricola (Jerdon, 1851) & 2 & 1 & 1 & 0 & 0 & 3 & 1 \\
\hline Nylanderia steinheili (Forel, 1893) & 0 & 0 & 1 & 0 & 0 & 0 & 0 \\
\hline Paratrechina longicornis (Latreille, 1802) & 1 & 2 & 1 & 0 & 6 & 0 & 0 \\
\hline Pheidole sp.1 & 0 & 0 & 0 & 2 & 9 & 0 & 0 \\
\hline Pseudomyrmex simplex (Smith, 1877) & 0 & 0 & 0 & 0 & 1 & 0 & 0 \\
\hline Solenopsis geminata (Fabricius, 1807) & 0 & 0 & 0 & 1 & 0 & 0 & 0 \\
\hline Tapinoma melanocephalum (Fabricius, 1793) & 1 & 2 & 3 & 0 & 0 & 0 & 0 \\
\hline Tetramorium bicarinatum (Nylander, 1846) & 9 & 0 & 0 & 0 & 0 & 0 & 0 \\
\hline Tetramorium simillimum (Smith, 1851) & 0 & 0 & 0 & 1 & 0 & 0 & 0 \\
\hline Number of mutualistic events recorded & 15 & 14 & 19 & 9 & 24 & 4 & 9 \\
\hline Number of species involved in mutualistic interaction & 5 & 5 & 10 & 5 & 7 & 2 & 4 \\
\hline
\end{tabular}

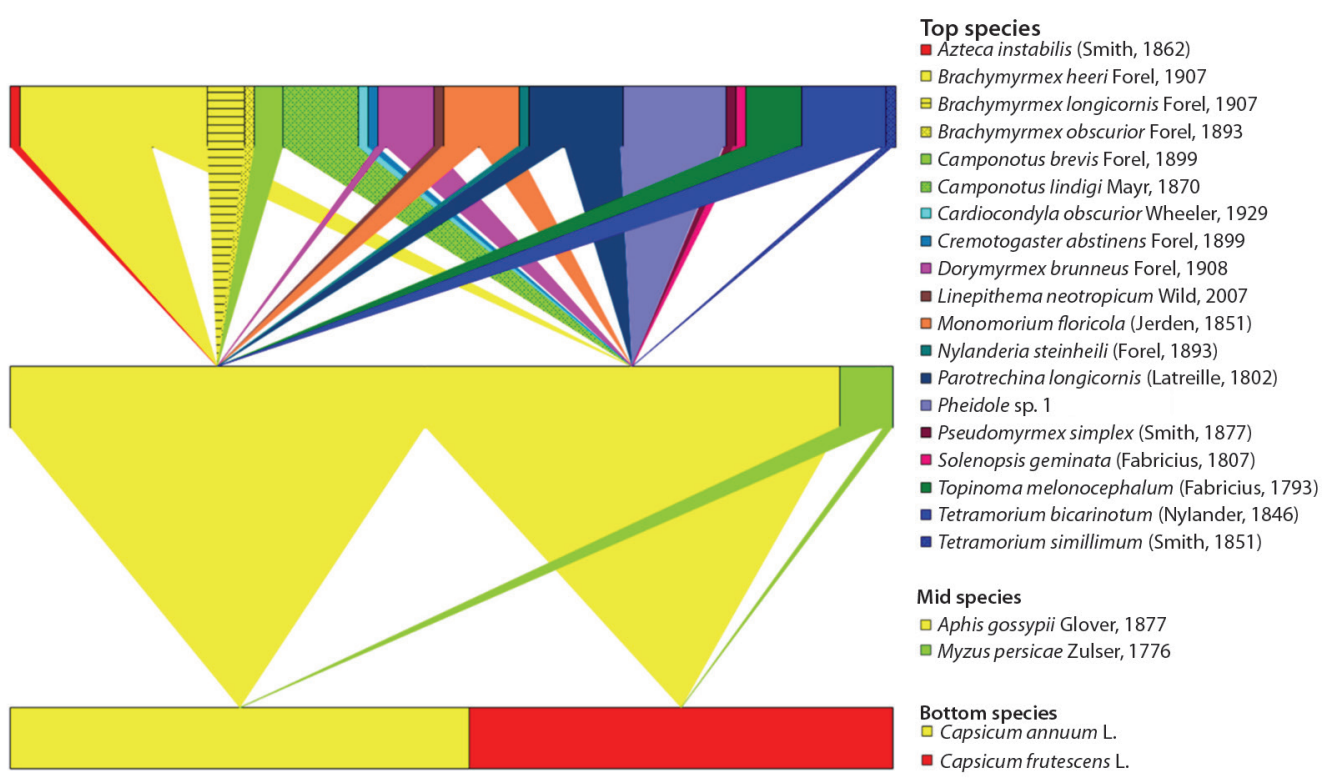

Fig. 3. Network illustrating the mutualistic relationship between ants and aphids that attack cayenne pepper C. annuum and tabasco pepper C. frutescens crops in Southwestern Colombia. 
listed in Table 1. Of the 19 species, 11 and 12 attended colonies of $A$. gossypii in cayenne and tabasco pepper crops, respectively (Fig. 3). Of these ant species, Brachymyrmex heeri (Forel, 1874), Dorymyrmex brunneus (Forel, 1908), Monomorium floricola (Jerdon, 1851) and Paratrechina longicornis (Latreille, 1802) were found in common between the two crops. $B$. heeri represented $21 \%$ of the interactions with aphids, as summarised in Table 1. The locality with the largest number of ant species attending to aphids was Toro, with a total of 10 species recorded. Finally, the species with the
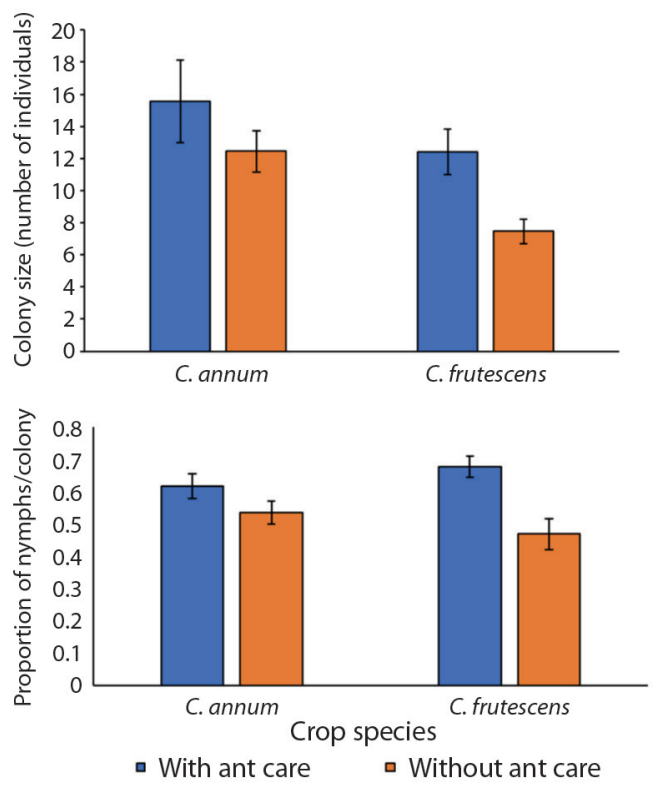

Fig. 4. Effect of ant care on the size of colonies and proportion of nymphs in colonies of $A$. gossypii established in cayenne and tabasco crops. The error bars indicate $95 \%$ confidence intervals. greatest distribution was $M$. floricola, which was recorded in five locations.

The colonies collected from $M$. persicae had an average colony size of 3 aphids, while A. gossypii had an average colony size of 10.5 aphids. Because only A. gossypii showed an interaction with ants, generalized linear models were estimated using the data of this species. This analysis indicates that $A$. gossypii colonies had a greater number of individuals when they were attended by ants for both crops $(\mathrm{P}<0.05)$, while the proportion of nymphs per colony was higher in colonies attended by ants for tabasco pepper $(\mathrm{P}<0.001)$ (Fig. 4, Table 2).

\section{DISCUSSION}

The biological identification of insect pests whose taxonomy is complex, such as aphids, is fundamental for establishing trophic interactions that may affect integrated pest management. Our results support the implementation of DNA barcoding as a cost-efficient aphid identification tool for non-specialists (Mazzi \& Dorn, 2012) because aphid species could be differentiated with certainty on a regional spatial scale using $9.5 \%$ of the adult specimens collected based on this tool and the availability of reference sequences in the NCBI. Other researchers have concluded that this tool is particularly helpful in identifying aphids, such as A. gossypii, which has different colour patterns in different hosts, e.g., Malvaceae, Cucurbitaceae and Solanaceae (Lokeshwari et al., 2014).

Although aphids in warm areas are anholocyclic and reproduce only by parthenogenesis (Blackman, 1974; Dixon, Kindlmann, Leps, \&

TABLE 2

Generalized linear models for colony size (number of individuals) and proportion of nymphs in colonies of $A$. gossypii established in cayenne pepper C. annuum and tabasco pepper C. frutescens

\begin{tabular}{cllcccc}
\multicolumn{1}{c}{ Crop } & \multicolumn{1}{c}{ Response var. } & \multicolumn{1}{c}{ Distr. error } & P (Chi) & DF resid. & Dev. Resid & $\begin{array}{c}\text { Effect of ants on } \\
\text { aphid colonies? }\end{array}$ \\
C. annuum & Colony size & Negative binomial & 0.0321 & 214 & 4.59 & Yes \\
& Nymphs/colony & Binomial & 0.0619 & 214 & 3.49 & No \\
\multirow{2}{*}{ C. frutescens } & Colony size & Negative binomial & $<0.001$ & 190 & 29.99 & Yes \\
& Nymphs/colony & Binomial & $<0.001$ & 190 & 12.28 & Yes \\
\hline
\end{tabular}


Holman, 1987), different phenotypes are presented depending on the stage of development of the insect, the host plant and environmental stress (Lokeshwari et al., 2014). Tálaga et al., (2017) reported that in C. annuum, M. persicae has a conserved phenotype during its different stages of development; however, on this same host, A. gossypii is polymorphic for body colour, and has a total of eleven phenotypes throughout its development. Our results are consistent with those reported by Tálaga et al., (2017) because we showed that in $C$. annuum and $C$. frutescens, the aphid $M$. persicae is monomorphic while A. gossypii shows polychromy. This pattern was consistent in the different locations of the inter-Andean valley of Southwestern Colombia. The molecular marker used here efficiently complemented the identification based on macroscopic morphological characteristics.

Although the DNA barcode has reported as a tool for conducting studies of genetic diversity and population genetics (Hebert \& Gregory, 2005), in the case of Aphididae, intraspecific variation at the mitochondrial level is low (Xu, Chen, Cheng, Liu, \& Francis, 2011). Moreover, the genetic diversity of these insects is much lower in areas where their introduction is more recent (Figueroa et al., 2005), which may explain the absence of intraspecific haplotype variation of $A$. gossypii and $M$. persicae at the sampled spatial scale because although the geographic origin of $A$. gossypii and M. persicae is not clear, Aphidinae is presumably native to temperate regions, especially of the Northern Hemisphere (Kim, Lee, \& Jang, 2011). The polyphagous species $A$. gossypii, for example, presents an intraspecific differentiation of 0.62 $\%$ according to Foottit et al., (2008), whose study included specimens from locations that span the geographic range of the species.

Many species of the family Aphididae are important pests in agriculture worldwide because in addition to direct damage to plants caused by their feeding, they transmit phytopathogenic viruses (Blanc, Uzest, \& Drucker, 2011; Fereres \& Raccah, 2015). Capsicum spp. crops worldwide are affected by viral diseases belonging to the families Bromoviridae and Potyviridae, and both A. gossypii and M. persicae are vectors of these phytopathogens (Kenyon et al., 2014). A. gossypii is a competent vector of cucumber mosaic virus (CMV) (Bromoviridae) and of chilli veinal mottle virus (CVMV) (Potyviridae) (Hooks \& Fereres, 2006; Kenyon et al., 2014), while M. persicae has been reported as a vector of CMV, pepper veinal mottle virus (PVMV) (Potyviridae) and potato virus Y (PVY) (Potyviridae) (Palukaitis, Roossinck, Dietzgen, \& Francki, 1992; Martín, Collar, Tjallingii, \& Fereres, 1997). In Southwestern Colombia, the pepper deforming mosaic virus (PepDMV) (Potyviridae: Potyvirus) has been reported as the predominant viral disease agent in Capsicum spp. (Pardey, Posso-Terranova, \& García, 2005); however, the persistence, distribution, and insect vectors of these diseases in these crop systems are unknown. A. gossypii and M. persicae have not been reported as PepDMV vectors; however, it is necessary to evaluate their role in the transmission of this disease because insects of Aphididae are strongly associated with viruses of the family Potyviridae.

The colonies of M. persicae were found in lower proportions and densities in comparison to the colonies of A. gossypii on cayenne and tabasco peppers, although both aphid species present similar values in terms of life cycle duration, longevity and fertility when grown on cayenne pepper under laboratory conditions (Tálaga et al., 2017). The low density in the colonies of $M$. persicae compared to those of A. gossypii on the same hosts can be explained by the regional context of the agricultural system of peppers in Southwestern Colombia. In Colombia, peppers are intensively planted in large-scale mechanized agricultural systems (Corporación Colombia Internacional, 2006), although on a small scale, they are also planted in home gardens. These crops grow as a sun-exposed monocrop in the inter-Andean valley of the Cauca River, with an average temperature of $23.3 \pm 6{ }^{\circ} \mathrm{C}$ and relative humidity of $79 \pm 2.4 \%$. These conditions limit the development of $M$. persicae, which has lower 
reproductive performance and slower development time compared to A. gossypii when the daily temperature is above $20{ }^{\circ} \mathrm{C}$ (Satar, Kersting, \& Uygun, 2008). A. gossypii shows optimal reproductive development above $17^{\circ} \mathrm{C}$ on plants of Capsicum spp. (Satar et al., 2008), explaining why the regional conditions of the inter-Andean valley of the Cauca River possibly constitute an advantage for the colonization of pepper plants by this aphid.

The ants present in the pepper crops did not attend to colonies of $M$. persicae, and the number and density of their colonies were lower than those of $A$. gossypii. Previous studies have reported that $A$. gossypii frequently establishes interactions with ants (Kaplan \& Eubanks, 2002; Kaplan \& Eubanks, 2005; Powell \& Silverman, 2010a) while M. persicae, which is considered a non-mutualistic species of aphid, does not (Powell \& Silverman, 2010b). Although M. persicae has the same ability to produce sugar exudates with carbohydrate quality similar to that generated by other aphid species (Hogervorst, Wäckers, \& Romeis, 2007), the ants do not interact with the colonies of this insect, and when both species are present, $M$. persicae is preferably consumed by the ants as prey (Powell \& Silverman, 2010b). The response behaviour of $M$. persicae to potential predators explains why it does not establish a relationship with ants because this species of aphid rapidly disperses from the colony when disturbed by natural enemies and ants (Nault, Montgomery, \& Bowers, 1976; Belliure, Amorós-Jiménez, Fereres, \& Marcos-García, 2011). Attendance by ants is more likely when the aphid species presents swarming behaviour because the area attended by ants is smaller (Stadler \& Dixon, 2005). In myrmecophiles (e.g., different species of the genus Aphis), the aphids of the colony are less easily dispersed or do not disperse in their interaction with ants because the alarm response is suppressed, which promotes the swarming behaviour of the colony (Nault et al., 1976).

Not all ant species attend to aphid colonies, and those that are involved in this interaction are opportunistic species that frequent extrafloral nectaries as a source of energetic resources (Delabie, 2001). In this study, species of Formicinae, Dolichoderinae and Myrmicinae were reported, and the genera reported in these subfamilies have been previously involved in this type of interaction with different species of Aphididae (Katayama \& Suzuki, 2003; Stadler \& Dixon, 2005; Buffa, Jaureguiberry, \& Delfino, 2009; Silva \& Perfecto, 2013; Campos \& Camacho, 2014). The species of these subfamilies are considered omnivorous, opportunistic ants that are typical of agroecosystems and intervened habitats (Fontenla \& Alfonso-Simonetti, 2018). Some species of Pseudomyrmex have been reported in this interaction with scale insects (Delabie, 2001; Ramírez, de Ulloa, Armbrecht, \& Calle, 2001; Buffa et al., 2009) and aphids (Delfino, 2005; Silva \& Perfecto, 2013). Species of this genus are considered to be general foragers and opportunistic predators (Fontenla \& Alfonso-Simonetti, 2018).

A. gossypii colonies attended by ants had a greater number of individuals, which may promote infestations of Capsicum spp. in Southwestern Colombia. Ant care is influenced by the quality (composition) and quantity of the honeydew (Völkl, Woodring, Fischer, Lorenz, \& Hoffmann, 1999; Katayama \& Suzuki, 2002), which indicates that a larger colony may be more tractive to be attended by ants. However, studies carried out by Hosseini et al., (2017), indicate that regardless of the initial size of the colony, this interaction generates an increase in the density of the colony and the growth rate is higher compared to the unattended colonies. On the other hand, aphids in small colonies invest more energy supplying the supply of honeydew for ants; in large colonies, this effort is less because more individuals contribute to supply the demand for this substance (Katayama \& Suzuki, 2002).

Studies carried out by Hosseini et al., (2017) and de Siqueira, Fagundes, Sperber and Fernandes (2011), indicate that this ant aphid interaction generates positive effects on the yield and biomass production of crop plants, among others, because the spread of 
microorganisms is prevented by avoiding the accumulation of aphid secretions, and the abundance of other herbivores is reduced. The interaction between A. gossypii and ants is of interest in biological control because ants interfere in the predation of this aphid by aphidophagous generalists, such as Hippodamia convergens Guérin-Méneville, 1842 (Coleoptera: Coccinellidae) and Chrysoperla carnea (Stephens) (Neuroptera: Chrysopidae) (Kaplan \& Eubanks, 2002; Powell \& Silverman, 2010a). Similarly, ant care reduces parasitism rates in A. gossypii colonies (Powell \& Silverman, 2010a). Despite the fact that direct ant interference by potential predators or parasitoids was not observed in the field, our results indicate a positive effect of ant care on the reproductive effectiveness of the colony (increased production of nymphs). In the context of aphids as virus vectors, the mutualistic interaction between aphids and ants of the Solenopsis invicta Buren species in tomato (Solanum lycopersicum L.) promotes aphid abundance and results in an increase in the number of plants affected by CMV (Cooper, 2005). Though, it is necessary to consider the aphid-ant interaction role in the propagation of viral diseases in commercial crops of Capsicum spp. and to determine how this interaction may affect regional biological control strategies.

The aphid species that infest commercial crops of cayenne pepper C. annuum and tabasco pepper $C$. frutescens are $A$. gossypii and $M$. persicae, which are potential vectors of the virus that affect Capsicum spp. in Southwestern Colombia. A total of 19 ant species were found attending the A. gossypii aphids, whose attended colonies were significantly larger than those not attended by ants in commercial crops. The mutualistic aphid-ant relationship thus promotes an increase in the size of the colonies of this aphid species. It is advisable to explore the effect that ants can have on the effectiveness of aphidophagous generalists and specialists in the context of integrated pest management for aphids in pepper crops in Southwestern Colombia.
Ethical statement: authors declare that they all agree with this publication and made significant contributions; that there is no conflict of interest of any kind; and that we followed all pertinent ethical and legal procedures and requirements. All financial sources are fully and clearly stated in the acknowledgements section. A signed document has been filed in the journal archives.

\section{ACKNOWLEDGMENTS}

The authors thank the farmers who allowed us to sample their crops and the technical team of Hugo Restrepo \& Co. for their field assistance. This research was co-financed by the General System of Royalties of Colombia (CIBIOFI BPIN-2013000100007), COLCIENCIAS, Government of Valle del Cauca, Universidad del Valle (Internal Call for Mobility Support - CIAM). We are grateful to the Postgraduate School in Biological Sciences at the University of Valle and Wilmar Torres for their advice on the statistical analyses.

\section{RESUMEN}

\section{Interacción mutualista de pulgones y hormigas en pimiento, Capsicum annuum y Capsicum frutenscens (Solanaceae)}

Introducción: La adecuada identificación biológica es fundamental para establecer programas de manejo integrado de plagas e identificar las relaciones tróficas y mutualistas que pueden afectar la dinámica poblacional de insectos plaga. Los áfidos son las principales plagas del ají Capsicum spp. (Solanaceae) en el suroccidente colombiano, debido a su rol como vectores de virus. Sin embargo, su identificación es compleja, y limita las investigaciones que intentan revelar sus interacciones con otros organismos. Las hormigas y los áfidos presentan una relación mutualista facultativa, que promueve el crecimiento de las colonias de los hemípteros, por esta razón, el estudio de la asociación ecológica y mutualista entre áfidos y hormigas es importante. Objetivo: El principal objetivo de esta investigación fue discriminar las especies de áfidos presentes en cultivos comerciales de Capsicum spp., e identificar la comunidad de hormigas que atiende las colonias de áfidos y su efecto en el tamaño de las colonias de áfidos. Métodos: los áfidos, y las hormigas mutualistas de estos áfidos, se recolectaron de Capsicum annuum y Capsicum frutescens, en el valle del rio Cauca, en el suroccidente 
colombiano. Se empleó el Código de barras del ADN para identificar las especies de áfidos, y las hormigas se identificaron empleando taxonomía basada en morfología. Para evaluar el efecto que tiene el cuidado de las hormigas sobre el tamaño de las colonias de áfidos, se empleó un modelo lineal generalizado, utilizando como variables de respuesta el número total de áfidos por cada colonia y la proporción de ninfas por colonia. Resultados: Las especies de áfidos que atacan los cultivos de ají, son: Aphis gossypii y Myzus persicae (Hemiptera: Aphididae), siendo A. gossypii la especie que interactúa con hormigas (19 especies). Las colonias de A. gossypii atendidas por hormigas presentan mayor tamaño y número de ninfas, que aquellas desatendidas. Conclusiones: Aunque la interacción áfido-hormiga no es especie específica, es necesario considerar su rol en la propagación de enfermedades virales en plantas cultivadas y determinar cómo esta interacción puede afectar la implementación de estrategias de control biológico.

Palabras clave: Aphis gossypii; Myzus persicae; COI; código de barras del ADN; hormigas.

\section{REFERENCES}

Altieri, M.A. (1999). The ecological role of biodiversity in agroecosystems. Agriculture, Ecosystems and Environment, 74(1), 19-31.

Armstrong, K.F., \& Ball, S.L. (2005). DNA barcodes for biosecurity: invasive species identification. Philosophical Transactions of the Royal Society B: Biological Sciences, 360(1462), 1813-1823. DOI: 10.1098/ rstb. 2005.1713

Belliure, B., Amorós-Jiménez, R., Fereres, A., \& Marcos-García, M.Á. (2011). Antipredator behaviour of Myzus persicae affects transmission efficiency of Broad bean wilt virus 1. Virus Research, 159(2), 206-214.

Billick, I., Hammer, S., Reithel, J.S., \& Abbot, P. (2007). Ant-Aphid Interactions: Are Ants Friends, Enemies, or Both? Annals of the Entomological Society of America, 100(6), 887-892. DOI: 10.1603/0013-8746(2007)100[887:AIAAFE]2.0. $\mathrm{CO} ; 2$

Blackman, R.L. (1974). Life-cycle variation of Myzus persicae (Sulz.) (Horn., Aphididae) in different parts of the world, in relation to genotype and environment. Bulletin of Entomological Research, 63(4), 595-607. DOI: $10.1017 / \mathrm{S} 0007485300047830$

Blackman, R.L., \& Eastop, V.F. (2007). Taxonomic Issues. In H.F. Van Emden \& R. Harrington (Eds.), Aphids as Crop Pests (pp. 1-29). London, UK: CABI.

Blanc, S., Uzest, M., \& Drucker, M. (2011). New research horizons in vector-transmission of plant viruses.
Current Opinion in Microbiology, 14(4), 483-491. DOI: 10.1016/j.mib.2011.07.008

Brault, V., Uzest, M., Monsion, B., Jacquot, E., \& Blanc, S. (2010). Aphids as transport devices for plant viruses. Comptes Rendus Biologies, 333(6-7), 524-538. DOI: 10.1016/j.crvi.2010.04.001

Buckley, R.C. (1987). Interactions involving plants, homoptera, and ants. Annual Review of Ecology and Systematics, 18(1), 111-135.

Buffa, L.M., Jaureguiberry, P., \& Delfino, M.A. (2009). Exudate-gathering ants (Hymenoptera; Formicidae) at three different liquid food rewards. Acta Zoológica Mexicana, 25(3), 515-526.

Campos, R.I., \& Camacho, G.P. (2014). Ant-plant interactions: the importance of extrafloral nectaries versus hemipteran honeydew on plant defense against herbivores. Arthropod-Plant Interactions, 8(6), 507-512.

California Academy of Sciences. (2020). AntWeb. (Version 8.41.). California Academy of Sciences, San Francisco, USA. Retrieved from https://www.antweb.org

Chen, R., Jiang, L.Y., \& Qiao, G.X. (2012). The effectiveness of three regions in mitochondrial genome for aphid DNA barcoding: a case in Lachininae. PloS One, 7(10), e46190. DOI: 10.1371/journal. pone. 0046190

Corporación Colombia Internacional. (2006). Plan Hortícola Nacional. Bogotá, Colombia: Ministerio de Agricultura y Desarrollo Rural.

Coeur d'acier, A., Cruaud, A., Artige, E., Genson, G., Clamens, A.L., Pierre, E., ... Rasplus, J.Y. (2014). DNA barcoding and the associated PhylAphidB@ se website for the identification of European aphids (Insecta: Hemiptera: Aphididae). PloS One, 9(6), e97620. DOI: 10.1371/journal.pone.0097620

Collins, C.M., \& Leather, S.R. (2002). Ant-mediated dispersal of the black willow aphid Pterocomma salicis L.; does the ant Lasius niger L. judge aphid-host quality? Ecological Entomology, 27(2), 238-241. DOI: 10.1046/j.1365-2311.2002.00390.x

Cooper, L.B. (2005). The potential effects of red imported fire ants (Solenopsis invicta) on arthropod abundance and Cucumber Mosaic Virus (Doctoral dissertation). Auburn University, Alabama, USA.

Cueto, V. (2006). Escalas en ecología: su importancia para el estudio de la selección de hábitat en aves. Horneo, $21,1-13$.

de Siqueira, F., Fagundes, M., Sperber, C.F., \& Fernandes, G.W. (2011). Tri-trophic level interactions affect host plant development and abundance of insect herbivores. Arthropod-Plant Interactions, 5(4), 351-357. 
Delabie, J.H.C. (2001). Trophobiosis Between Formicidae and Hemiptera (Sternorrhyncha and Auchenorrhyncha): an Overview. Neotropical Entomology, 30(4), 501-516. DOI: 10.1590/S1519-566X2001000400001

Delfino, M.A. (2005). Inventario de las asociaciones áfido-planta en el Perú. Ecología Aplicada, 4(1-2), 143-148.

Dixon, A.F.G., Kindlmann, P., Leps, J., \& Holman, J. (1987). Why there are so few species of aphids, especially in the tropics. The American Naturalist, $129(4), 580-592$

Fereres, A., \& Raccah, B. (2015). Plant Virus Transmission by Insects The Major Transmission Modes. eLS, 2015, 1-12. DOI: 10.1002/9780470015902. a0000760.pub3

Fernández, F., Guerrero, R.J., \& Delsinne, T. (2019). Hormigas de Colombia. Bogotá, Colombia: Universidad Nacional de Colombia.

Figueroa, C.C., Simon, J.C., Le Gallic, J.F., Prunier-Leterme, N., Briones, L.M., Dedryver, C.A., \& Niemeyer, H.M. (2005). Genetic structure and clonal diversity of an introduced pest in Chile, the cereal aphid Sitobion avenae. Heredity, 95(1), 24-33. DOI: 10.1038 sj.hdy. 6800662

Folmer, O., Black, M., Hoeh, W., Lutz, R., \& Vrijenhoek, R. (1994). DNA primers for amplification of mitochondrial cytochrome $\mathrm{c}$ oxidase subunit I from diverse metazoan invertebrates. Molecular Marine Biology and Biotechnology, 3(5), 294-299.

Fontenla, J.L., \& Alfonso-Simonetti, J. (2018). Classification of cuban ants (Hymenoptera: Formicidae) into functional groups. Revista Cubana de Zoología, 506, 21-30.

Foottit, R.G. (1997). Recognition of parthenogenetic insect species. In M.F. Claridge, H.A. Dawah, \& M.R. Wilson (Eds.), The Units of Biodiversity (pp. 291-307). London, UK: Chapman and Hall Ltd.

Foottit, R.G., Maw, H.E.L., Havill, N.P., Ahern, R.G., \& Montgomery, M.E. (2009). DNA barcodes to identify species and explore diversity in the Adelgidae (Insecta: Hemiptera: Aphidoidea). Molecular Ecology Resources, 9(1), 188-195. DOI: 10.1111/j.1755-0998.2009.02644.x

Foottit, R.G., Maw, H.E.L., Von Dohlen, C.D., \& Hebert, P.D.N. (2008). Species identification of aphids (Insecta: Hemiptera: Aphididae) through DNA barcodes. Molecular Ecology Resources, 8(6), 1189-1201. DOI: 10.1111/j.1755-0998.2008.02297.x

Goggin, F.L. (2007). Plant-aphid interactions: molecular and ecological perspectives. Current Opinion in Plant Biology, 10(4), 399-408.
Hebert, P.D.N., Cywinska, A., \& Ball, S.L. (2003). Biological identifications through DNA barcodes. Proceedings of the Royal Society of London B: Biological Sciences, 270(1512), 313-321.

Hebert, P.D.N., \& Gregory, T.R. (2005). The promise of DNA barcoding for taxonomy. Systematic Biology, 54(5), 852-859.

Hogervorst, P.A.M., Wäckers, F.L., \& Romeis, J. (2007). Effects of honeydew sugar composition on the longevity of Aphidius ervi. Entomologia Experimentalis et Applicata, 122(3), 223-232.

Holman, J. (1974). Los áfidos de Cuba. La Habana, Cuba: Instituto Cubano del Libro.

Hooks, C.R.R., \& Fereres, A. (2006). Protecting crops from non-persistently aphid-transmitted viruses: A review on the use of barrier plants as a management tool. Virus Research, 120, 1-16. DOI: 10.1016/j. virusres.2006.02.006

Hosseini, A., Hosseini, M., Katayama, N., \& Mehrparvar, M. (2017). Effect of ant attendance on aphid population growth and above ground biomass of the aphid's host plant. European Journal of Entomology, 114 116-117. DOI: 10.14411/eje.2017.015

Instituto Geográfico Agustín Codazzi (1998). Valle del Cauca: Aspectos geográficos. Bogotá, Colombia: Instituto Geográfico Agustín Codazzi.

Kaplan, I., \& Eubanks, M.D. (2002). Disruption of cotton aphid (Homoptera: Aphididae)-natural enemy dynamics by red imported fire ants (Hymenoptera: Formicidae). Environmental Entomology, 31(6), 1175-1183.

Kaplan, I., \& Eubanks, M.D. (2005). Aphids alter the community-wide impact of fire ants. Ecology, 86(6), 1640-1649.

Katayama, N., \& Suzuki, N. (2002). Cost and benefit of ant attendance for Aphis craccivora (Hemiptera: Aphididae) with reference to aphid colony size. The Canadian Entomologist, 134(2), 241-249.

Katayama, N., \& Suzuki, N. (2003). Changes in the use of extrafloral nectaries of Vicia faba (Leguminosae) and honeydew of aphids by ants with increasing aphid density. Annals of the Entomological Society of America, 96(4), 579-584.

Kenyon, L., Kumar, S., Tsai, W.S., \& Hughes, J.A. (2014). Virus diseases of peppers (Capsicum spp.) and their control. Advances in Virus Research, 90, 297-354. DOI: 10.1016/B978-0-12-801246-8.00006-8

Kim, H., Lee, S., \& Jang, Y. (2011). Macroevolutionary patterns in the Aphidini aphids (hemiptera: Aphididae): Diversification, host association, and biogeographic origins. PLOS ONE, 6(9), e24749. DOI: 10.1371/journal.pone.0024749 
Kumar, S., Stecher, G., Tamura, K., \& Dudley, J. (2016). MEGA7: Molecular Evolutionary Genetics Analysis Version 7.0 for Bigger Datasets. Molecular Biology and Evolution, 33(7), 1870-1874. DOI: 10.1093/ molbev/msw054

Lokeshwari, D., Kumar, N.K.K., \& Manjunatha, H. (2014). Color polymorphism does not affect species diagnosis of the melon aphid, Aphis gossypii (Hemiptera: Aphididae). Florida Entomologist, 97(3), 1199-1207.

Martín, B., Collar, J.L., Tjallingii, W.F., \& Fereres, A. (1997). Intracellular ingestion and salivation by aphids may cause the acquisition and inoculation of non-persistently transmitted plant viruses. Journal of General Virology, 78(10), 2701-2705. DOI: 10.1099/0022-1317-78-10-2701

Matson, P.A., Parton, W.J., Power, A.G., \& Swift, M.J. (1996). Agricultural intensification and ecosystem properties. Science, 277(5325), 504-509.

Mazzi, D., \& Dorn, S. (2012). Movement of insect pests in agricultural landscapes. Annals of Applied Biology, 160(2), 97-113. DOI: 10.1111/j.1744-7348.2012.00533.x

Miller, G.L., \& Foottit, R.G. (2009). The Taxonomy of Crop Pests: The Aphids. In R.G. Fottit \& P.H. Adler (Eds.), Insect Biodiversity: Science and Society (pp. 463-473). New Jersey, USA: Wiley-Blackwell.

Montoya-Colonia, A.M. (2010). Conformación del mapa de ecosistemas del Valle del Cauca empleando sistemas de información geográfica. Ventana Informática, $22,11-38$.

Nault, L.R., Montgomery, M.E., \& Bowers, W.S. (1976). Ant-aphid association: role of aphid alarm pheromone. Science, 192(4246), 1349-1351. DOI: 10.1126/ science. 1273595

Nie, X., Pelletier, Y., Mason, N., Dilworth, A., \& Giguère, M.A. (2011). Aphids preserved in propylene glycol can be used for reverse transcription-polymerase chain reaction detection of Potato virus Y. Journal of Virological Methods, 175(2), 224-227.

Palukaitis, P., Roossinck, M.J., Dietzgen, R.G., \& Francki, R.I.B. (1992). Cucumber mosaic virus. Advances in Virus Research, 41, 281-348.

Pardey, C., \& García, M.A. (2011). Mejoramiento en Capsicum al virus del mosaico deformante del pimentón (PEPDMV). INTROPICA Revista del Instituto de Investigaciones Tropicales, 6(1), 33-39.

Pardey, C., Posso-Terranova, A.M., \& García, M.A. (2005). Evaluación de accesiones de Capsicum spp. por su reacción al virus del mosaico deformante del pimentón (PepDMV). Acta Agronómica, 59(1), 97-102.

Pelletier, Y., Nie, X., Giguère, M.A., Nanayakkara, U., Maw, E., \& Foottit, R. (2012). A new approach for the identification of aphid vectors (Hemiptera: Aphididae) of Potato virus Y. Journal of Economic Entomology, 105(6), 1909-1914.

Piffaretti, J., Vanlerberghe-Masutti, F., Tayeh, A., Clamens, A.L., D’Acier, A.C., \& Jousselin, E. (2012). Molecular phylogeny reveals the existence of two sibling species in the aphid pest Brachycaudus helichrysi (Hemiptera: Aphididae). Zoologica Scripta, 41(3), 266-280. DOI: 10.1111/j.1463-6409.2012.00531.x

Powell, B.E., \& Silverman, J. (2010a). Impact of Linepithema humile and Tapinoma sessile (Hymenoptera: Formicidae) on three natural enemies of Aphis gossypii (Hemiptera: Aphididae). Biological Control, 54(3), 285-291. DOI: 10.1016/J. BIOCONTROL.2010.05.013

Powell, B.E., \& Silverman, J. (2010b). Population growth of Aphis gossypii and Myzus persicae (Hemiptera: Aphididae) in the presence of Linepithema humile and Tapinoma sessile (Hymenoptera: Formicidae). Environmental Entomology, 39(5), 1492-1499.

Puillandre, N., Lambert, A., Brouillet, S., \& Achaz, G. (2012). ABGD, Automatic Barcode Gap Discovery for primary species delimitation. Molecular Ecology, $21,1864-1877$.

R Core Team. (2018). R: A language and environment for statistical computing. R Foundation for Statistical Computing, Vienna, Austria. Retrieved from http// www.R-project.org/

Ramírez, M., de Ulloa, P.C., Armbrecht, I., \& Calle, Z. (2001). Contribución al conocimiento de las interacciones entre plantas, hormigas y homópteros en bosques secos de Colombia. Caldasia, 23(2), 523-536.

Ratnasingham, S., \& Hebert, P.D.N. (2007). BOLD: The Barcode of Life Data System. Molecular Ecology Notes, 7(3), 355-364. Retrieved from http://www. barcodinglife. org

Rusch, A., Bommarco, R., \& Ekbom, B. (2017). Conservation Biological Control in Agricultural Landscapes. Advances in Botanical Research, 81, 333-360. DOI: 10.1016/BS.ABR.2016.11.001

Satar, S., Kersting, U., \& Uygun, N. (2008). Effect of temperature on population parameters of Aphis gossypii Glover and Myzus persicae (Sulzer) (Homoptera: Aphididae) on pepper. Journal of Plant Diseases and Protection, 115(2), 69-74. DOI: 10.1007/BF03356241

Silva, E.N., \& Perfecto, I. (2013). Coexistence of Aphid Predators in Cacao Plants: Does Ant-aphid Mutualism Play a Role? Sociobiology, 60(3), 259-265.

Sint, D., \& Traugott, M. (2016). Food Web Designer: a flexible tool to visualize interaction networks. Journal of Pest Science, 89(1), 1-5. DOI: 10.1007/ s10340-015-0686-7 
Stadler, B., \& Dixon, A.F.G. (2005). Ecology and Evolution of Aphid-Ant Interactions. Annual Review of Ecology, Evolution, and Systematics, 36(1), 345-372. DOI: 10.1146/annurev.ecolsys.36.091704.175531

Styrsky, J.D., \& Eubanks, M.D. (2007). Ecological consequences of interactions between ants and honeydew-producing insects. Proceedings of the Royal Society of London. Series B, 274(1607), 151-164. DOI: $10.1098 / \mathrm{rspb} .2006 .3701$

Tálaga, W., Lagos, Y., Melo, C., Duque-Gamboa, D., Toro-Perea, N., \& Manzano, M.R. (2017). Expandiendo el conocimiento de plagas del aji en Colombia: Identificación y biología de áfidos (Hemiptera: Aphididae). Memorias \& Resúmenes, 44 Congreso SOCOLEN (Sociedad Colombiana de Entomología), Bogotá, Colombia.
Van Emden, H.F., \& Harrington, R. (2003). Aphids as crop pests. London, UK: CABI.

Völkl, W., Woodring, J., Fischer, M., Lorenz, M.W., \& Hoffmann, K.H. (1999). Ant-aphid mutualisms: the impact of honeydew production and honeydew sugar composition on ant preferences. Oecologia, 118(4), 483-491.

Xu, Z.H., Chen, J., Cheng, D.F., Liu, Y., \& Francis, F. (2011). Genetic variation among the geographic population of the grain aphid, Sitobion avenae (Hemiptera: Aphididae) in China inferred from mitochondrial COI gene sequence. Agricultural Sciences in China, 10(7), 1041-1048.

Yao, I. (2014). Costs and constraints in aphid-ant mutualism. Ecological Research, 29(3), 383-391. 